\title{
Erratum to: Differences in monoterpene emission characteristics after ozone exposure between three clones representing major gene pools of Cryptomeria japonica
}

\author{
Takafumi MiYama ${ }^{\mathrm{a}, \dagger}$, Hiroyuki Tobita ${ }^{\mathrm{a}}$, Kentaro UchiYAma ${ }^{\mathrm{a}}$, Kenichi Yazaki ${ }^{\mathrm{a}}$, Saneyoshi Ueno ${ }^{\mathrm{a}}$, \\ Takami Saito ${ }^{a}$, Asako Matsumoto ${ }^{\mathrm{a}}$, Mitsutoshi Kitao ${ }^{\mathrm{b}}$ and Takeshi Izuta ${ }^{\mathrm{c}}$ \\ ${ }^{a}$ Forestry and Forest Products Research Institute, 1 Matsunosato, Tsukuba, Ibaraki 305-8687, Japan \\ ${ }^{\mathrm{b}}$ Hokkaido Research Center, Forestry and Forest Products Research Institute, \\ 7 Hitsujigaoka, Toyohira, Sapporo, Hokkaido 062-8516, Japan \\ ${ }^{\mathrm{c}}$ Institute of Agriculture, Tokyo University of Agriculture and Technology, 3-5-8 Saiwaicho, Fuchu, Tokyo 183-8509, Japan
}

The Editorial Office of Journal of Agricultural Meteorology wishes to correct the errors in this paper (Miyama et al. 2018). Figure 3 and the caption should be as followed.

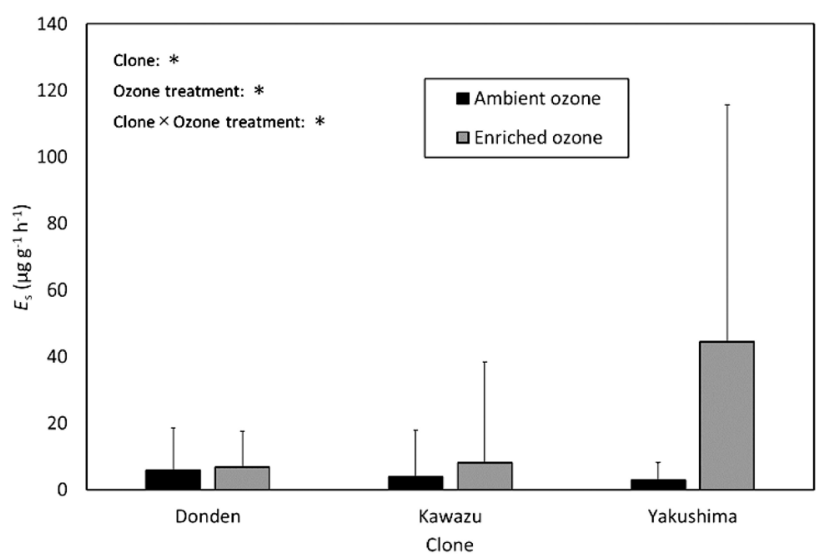

Fig. 3. Comparison of mean basal emission rate $\left(E_{\mathrm{s}}\right)$ between plots. Error bars indicate standard error $(\mathrm{n}=6)$. Asterisks indicate statistical differences $(p<0.05)$ analyzed by ANOVA. Enriched ozone plots controlled the concentration to twice-ambient. There were significant differences $(p<0.05)$ between Yakushima clone in enriched ozone plots and another.

\section{References}

Miyama T, Tobita H, Uchiyama K, Yazaki K, Ueno S, Saito T, Matsumoto A, Kitao M, Izuta T, 2018: Differences in monoterpene emission characteristics after ozone exposure between three clones representing major gene pools of Cryptomeria japonica. Journal of Agricultural Meteorology 74(3), 102-108. 